AperTO - Archivio Istituzionale Open Access dell'Università di Torino

\title{
Human skin penetration of gold nanoparticles through intact and damaged skin
}

\section{This is the author's manuscript}

Original Citation:

Availability:

This version is available http://hdl.handle.net/2318/85358

since 2016-11-28T07:32:46Z

Published version:

DOI:10.3109/17435390.2010.551428

Terms of use:

Open Access

Anyone can freely access the full text of works made available as "Open Access". Works made available under a Creative Commons license can be used according to the terms and conditions of said license. Use of all other works requires consent of the right holder (author or publisher) if not exempted from copyright protection by the applicable law. 
This is the author's final version of the contribution published as:

Larese Filon F; Crosera M; Adami G; Bovenzi M; Rossi F; Maina G. Human skin penetration of gold nanoparticles through intact and damaged skin.

NANOTOXICOLOGY. 5(4) Epub 2011 Feb 14 pp: 493-501.

DOI: $10.3109 / 17435390.2010 .551428$

The publisher's version is available at:

http://www.tandfonline.com/doi/full/10.3109/17435390.2010.551428

When citing, please refer to the published version.

Link to this full text:

http://hdl.handle.net/2318/85358 


\title{
HUMAN SKIN PENETRATION OF GOLD NANOPARTICLES THROUGH INTACT AND DAMAGED SKIN
}

\author{
Francesca Larese Filon ${ }^{1}$, Matteo Crosera ${ }^{2}$, Gianpiero Adami ${ }^{2}$, Massimo Bovenzi ${ }^{1}$, Federica Rossi ${ }^{3}$, \\ Giovanni Maina ${ }^{3}$ \\ ${ }^{1}$ UCO Medicina del Lavoro, Dipartimento di Scienze di Medicina Pubblica \\ ${ }^{2}$ Dipartimento di Scienze Chimiche, Università di Trieste, Trieste, Italy \\ ${ }^{3}$ Dipartimento di Traumatologia Ortopedia e Medicina del Lavoro, Università di Torino, Torino, \\ Italy
}

\begin{abstract}
Gold nanoparticles (AuNPs) are produced for many applications but there is a lack of available data on their skin absorption. Experiments were performed using the Franz diffusion cell method with intact and damaged human skin. A physiological solution was used as receiving phase and $0.5 \mathrm{~mL}$ (1st exp) and $1.5 \mathrm{~mL}$ (2nd exp) of a solution containing $100 \mathrm{mgL}^{-1}$ of AuNPs $\left(15\right.$ and $45 \mathrm{mg} \mathrm{cm}^{-2}$, respectively) was applied as donor phase to the outer surface of the skin for $24 \mathrm{~h}$. Skin absorption was dose dependent. Mean gold content of $214.0 \pm 43.7 \mathrm{ng} \mathrm{cm}^{-2}$ and $187.7 \pm 50.2 \mathrm{ng} \mathrm{cm}^{-2}$ were found in the receiving solutions of cells where the AuNPs solution was applied in higher concentration on intact skin (8 Franz cells) and on damaged skin (8 Franz cells), respectively. Twenty-four hours gold flux permeation was $7.8 \pm 2.0 \mathrm{ng} \mathrm{cm}-2 \mathrm{~h}^{-1}$ and $7.1 \pm 2.5 \mathrm{ng} \mathrm{cm}-2 \mathrm{~h}^{-1}$ in intact and damaged skin, respectively, with a lag time less than 1 hour. Transmission Electron Microscope analysis on skin samples and chemical analysis using Inductively Coupled PlasmaMass Spectrometry demonstrated the presence of AuNPs into epidermis and dermis. This study showed that AuNPs are able to penetrate the human skin in an in vitro diffusion cell system.
\end{abstract}

Keywords: Nanoparticles, gold, skin absorption, in vitro, damaged skin

\section{Introduction}

Over the past decades a huge interest in nanotechnologies has risen throughout the world because they have been considered revolutionary in many fields: Materials at the nanometer scale show different properties compared to the bulk forms with the same composition. In particular, nanoparticles with many different structures, due to their small size (100 nm or less) comparable to that of biological molecules, represent an enormous opportunity in the life sciences and in the medical field. Among these new nanocompounds, gold nanomaterials (AuNPs) are particularly attractive since their valuable size and shape-dependent properties are easy to control and modify; these characteristics offer powerful tools for the activity of the researchers and AuNPs have been proposed for a number of applications in many different fields (Penn et al. 2003; Gupta and Gupta 2005; Neuberger et al. 2005; Chen et al. 2008). Many studies have been carried out on the use of modified gold nanomaterials in the imaging and therapy of tumors (El-Sayed et al. 2006; Bhattacharya and Mukherjee 2008); in the intracellular gene regulation for the control of protein expression in cells (Rosi et al. 2006), in the direct welding of connective tissues (Gobin et al. 2005; Ratto et al. 2009); but their use has also been proposed as immunostaining marker particles for electron microscopy, chromophores for immunoreactions (Mirkin et al. 1996), photocatalyst (Kamat 2002) and Raman sensors (Tian et al. 2002). AuNPs are also rising as a lead candidate in the transport of payloads within inside tissues and cells for drug delivery, gene therapy and cell imaging (Ghosh et al. 2008).

AuNPs are stable in the body (Niidome et al. 2006) and so they have been largely used to study the tissue distribution, following administration through different routes (Semmler-Behnke et al. 2008; 
Sonavane et al. 2008a; Cho et al. 2009; Balasubramanian et al. 2010). However the safety of their use is a matter of concern and more data are needed to better understand their biocompatibility, their side-effects, and their fate in the body (Takahashi et al. 2006; Lewinski et al. 2008). In fact, a number of studies have reported that AuNPs can be toxic for cells because the uptake of gold clusters by different types of cells and their interaction with DNA have been demonstrated.

Focusing on skin cells, Pernodet et al. (2006) investigated the effects of citrate/gold nanoparticles at different concentrations and exposure times on human dermal fibroblasts. They found that, as a result of the intracellular nanoparticle presence, actin stress fibers disappeared, thereby inducing major adverse effects on cell viability. Properties such as cell spreading and adhesion, cell growth, and protein synthesis to form the extracellular matrix were altered dramatically, suggesting that the internal cell activities were damaged. On the contrary, Wang et al. (2008) tested the cytotoxicity of different size and shape gold nanomaterial on HaCaT keratinocytes and concluded that it is difficult to understand the cytotoxicity of gold nanomaterials individually, indeed spherical AuNPs were not inherently toxic to human skin cells, but gold nanorods were highly toxic due to the presence of the coating material. Finally, Mironava et al. (2010) described the interactions of AuNPs with human dermal fibroblasts and demonstrated that they can penetrate the plasma membrane and accumulate in large vacuoles in a time, size and concentration depending manner. Authors also provided evidences of some toxic effects as cytoskeleton filament disruption, decreased expression of the extracellular matrix proteins and decrease of the proliferation rates, but these detrimental effects on cell functions can reverse following AuNPs removal and cells can completely recover as a function of AuNPs size, concentration and exposure time.

Among the great number of applications, AuNPs would be an interesting carrier for transdermal delivery (Chen et al. 2008) but to our knowledge, there are no data on their skin permeation in in vitro system using human skin. Only Sonavane et al. (2008b) investigated the in vitro cutaneous penetration of three types of AuNPs differing in size (15 nm, $102 \mathrm{~nm}$ and $198 \mathrm{~nm})$ using the Franz diffusion cell method with rat skin. AuNPs showed size-dependent permeation through rat skin: 15 $\mathrm{nm}$ AuNPs showed higher permeation compared to $102 \mathrm{~nm}$ and $198 \mathrm{~nm}$ AuNPs. TEM study of rat skin revealed accumulation of smaller size nanoparticles in deeper skin regions whereas larger particles were observed mainly in epidermis and dermis.

To investigate the potential of AuNPs skin absorption in vitro, we carried out a series of permeation experiments with human skin using a Franz static diffusion cell (Franz 1975). Using this technique, we investigated the total amount of gold permeating through human skin during a 24-h period. Experiments were run with intact skin as well as abraded skin following the Bronaugh and Stewart (1985) protocol to estimate the effect of skin lesions on the permeation rate. In this study, we applied the protocol adopted in the European project EDETOX (Evaluations and predictions of DErmal absorption of TOXic chemicals), a three-year research program (2001-2004) financially supported by the European Commission, and already used by our group to study the in vitro dermal absorption of silver nanoparticles (Larese Filon et al. 2009a).

\section{Materials and methods}

\section{Chemicals}

All chemicals were analytical grade. Magnesium nitrate hexahydrate, palladium nitrate, sodium hydrogenphosphate, potassium dihydrogenphosphate, and hydrogen peroxide $(30 \% \mathrm{v} / \mathrm{v})$ were purchased from Carlo Erba (Milan, Italy); sodium tetrachloroauric acid, trisodium citrate dihydrate, nitric acid (>69\% v/v) and hydrochloric acid (36.5-38\% v/v) from Sigma Aldrich (Milan, Italy). Water reagent grade was produced with a Millipore purification pack system (milliQ water). The physiological solution used as the receptor fluid was prepared by dissolving $2.38 \mathrm{~g}$ of $\mathrm{Na}_{2} \mathrm{HPO}_{4}$, $0.19 \mathrm{~g}$ of $\mathrm{KH}_{2} \mathrm{PO}_{4}$ and $9 \mathrm{~g}$ of $\mathrm{NaCl}$ into $1 \mathrm{~L}$ of milliQ water (final $\mathrm{pH}=7.35$ ). 
The synthetic sweat solution used as the donor fluid included $0.5 \%$ sodium chloride, $0.1 \%$ urea and $0.1 \%$ lactic acid in milliQ water; $\mathrm{pH} 4.5$ was adjusted with ammonia.

\section{Nanoparticle synthesis and characterization}

AuNPs were synthesized by reducing tetrachloroauric acid with sodium citrate as described by Grabar et al. (1995). Transmission Electron Microscopy (TEM) was used to evaluate the size and stability of nanoparticles before and after the experiments.

Total gold concentration was analyzed by Inductively Coupled Plasma-Atomic Emission Spectroscopy (ICP-AES): $1 \mathrm{~mL}$ of AuNPs suspension was treated with $1 \mathrm{~mL}$ of Aqua Regia (a solution having concentrated nitric acid and concentrated hydrochloric acid mixed at a volume ratio of 1:3) at room temperature and the volume was adjusted to $10 \mathrm{~mL}$ with milliQ water. The gold solution was measured at a wavelength of $267,595 \mathrm{~nm}$. A five-point standard

curve was used for the analytical measurements. The correlation coefficient of the standard curve was 0.9989 . The samples were analyzed by measuring against standard solutions for instrumental calibration. The coefficient of variation (CV) for the analysis was less than $3 \%$ and the limit of detection was $0.050 \mathrm{mg} \mathrm{L}^{-1}$. The determined concentration of gold in the initial nanoparticle suspension was $100 \pm 5 \mathrm{mg} \mathrm{L}^{-1}(\mathrm{n}=3)$.

\section{Preparation of skin membranes}

Human abdominal full thickness skin was obtained as surgical waste after the authorization of the local Ethical Committee. Prior to freezing, the subcutaneous fat was removed and the hair shaved with a razor. All the pieces of full thickness skin were stored in freezer at $-25^{\circ} \mathrm{C}$ for a period up to, but not exceeding, two months. It has been shown that this method of storage does not damage the skin since no difference in permeability was observed between fresh and frozen segments of the same skin in a separate series of experiments (Franz 1975). Skin integrity was tested before and after each experiment using electrical conductibility by means of a conductometer (Metrohm, 660, Metrohm AG Oberdorfstr. $68 \mathrm{CH}-9100 \mathrm{Herisau}$ ) operating at $300 \mathrm{~Hz}$ and connected to two stainless steel electrodes (Fasano et al. 2009). The conductibility data in $\mu \mathrm{S}$ were converted into K $\Omega$ $\mathrm{cm}^{-2}$. Franz cells with a resistance lower than $3.95 \pm 0.27 \mathrm{~K} \Omega \mathrm{cm}^{-2}$ were considered to be damaged and rejected as suggested by Davies et al. (2004). Donors were men and women with a wide range of age (41-71 years).

\section{In vitro diffusion system}

Percutaneous absorption studies were performed using static diffusion Franz cells (Franz 1975). The receptor compartment had a mean volume of $14.0 \mathrm{~mL}$ and was maintained at $32^{\circ} \mathrm{C}$ by means of circulation of thermostated water in the jacket surrounding the cell. This temperature value was chosen in order to reproduce the hand physiological temperature at normal conditions. The physiological solution used as the receptor fluid was prepared by dissolving $2.38 \mathrm{~g}$ of $\mathrm{Na}_{2} \mathrm{HPO}_{4}$, $0.19 \mathrm{~g}$ of $\mathrm{KH}_{2} \mathrm{PO}_{4}$ and $9 \mathrm{~g}$ of $\mathrm{NaCl}$ into $1 \mathrm{~L}$ of milliQ water (final $\mathrm{pH}=7.35$ ).

The concentration of the salt in the receptor fluid was approximately the same as the one found in the blood. The solution in each cell was continuously stirred using a Teflon-coated magnetic stirrer. Each piece of skin was clamped between the donor and the receptor compartment; the mean exposed skin area was $3.29 \mathrm{~cm}^{2}$ and the average thickness of the membranes was $1 \mathrm{~mm}$. The experiments were carried out as follows:

Experiment 1: At time 0, the exposure chambers of 8 Franz diffusion cells were filled with $0.5 \mathrm{~mL}$ of a solution containing $100 \mathrm{mg} \mathrm{L}^{-1}$ of AuNPs $\left(15 \mathrm{mg} \mathrm{cm}^{-2}\right)$ and diluted 1:3 with synthetic sweat at $\mathrm{pH} 4.5$ to reproduce in vivo condition. The protocol used was the same of our previous paper 
(Larese Filon et al. 2009a). At $24 \mathrm{~h}$, the dermal bathing solution was removed and the gold concentration was determined in each receiving chamber solution.

Experiment 2: Experiment 1 was repeated using an abraded skin protocol as suggested by Bronaugh and Stewart (1985): The skin was abraded by drawing the point of a 19-gauge hypodermic needle across the surface (20 marks in one direction and 20 perpendicular).

Experiment 3: At time 0, the exposure chambers of 8 Franz diffusion cells were filled with $1.5 \mathrm{~mL}$ solution containing $100 \mathrm{mg} \mathrm{L}^{-1}$ of nanoparticles solution $(45 \mathrm{mg} \mathrm{cm}-2)$ diluted 1:3 with milliQ water. At selected intervals $(4,8,16,24 \mathrm{~h}) 1.5 \mathrm{~mL}$ of the dermal bathing solution was removed and analyzed. Each receptor sample was immediately replaced with an equal volume of fresh physiological solution.

Experiment 4: Experiment 3 was repeated using the abraded skin protocol described above. Blanks: For each experiment, four Franz cells were added as blank. The blank Franz cells were treated as the other cells with the exception that no AuNPs was introduced to the exposure chamber. Experiments 1 and 2 were preliminary tests to evaluate nanoparticles permeation using the same protocol reported previously (Larese Filon et al. 2009a). Experiments 3 and 4 were performed using a higher gold concentration in milliQ water to avoid interference between AuNP and synthetic sweat.

\section{Skin content evaluation}

After the experiments 3 and 4, the skin pieces were removed from the diffusion Franz cells and treated in two different ways: Damaged skin samples were simply stored in freezer at $-25^{\circ} \mathrm{C}$, while intact skin samples were separated into epidermis and dermis by heat shock immerging in water at $60^{\circ} \mathrm{C}$ for $1 \mathrm{~min}$. Before this operation, the stratum corneum (SC) of three intact skin samples was removed by stripping with PVC adhesive tape (Tesa-Beiersdorf AG, Ham- burg, Germany) in order to evaluate the gold content in different skin layers. Constant and uniform pres- sure $\left(100 \mathrm{~g} \mathrm{~cm}^{-2}\right)$ was applied on the tape for $5 \mathrm{sec}$ by resting an appropriate weight on the area, and the tape than gradually removed from the skin in a one draw (Hostynek et al. 2001). It has been demonstrated that when applying the same pressure to the skin, after the first 2-20 strips, for a given skin site and test subject each tape remove a constant amount of SC (Hostynek et al. 2001). We chose to strip the skin only six times in order to prevent the damage of the epidermis after the $24^{\text {-h }}$ period of exposure. All the skin fractions were collected and stored individually in freezer at $-25^{\circ} \mathrm{C}$ for the following digestion and analysis. At the time of the analysis, the skin membranes were dried for $2 \mathrm{~h}$ at room temperature, then cut into sections and put into beakers with $25 \mathrm{~mL}$ of $\mathrm{HNO}_{3} 70 \% \mathrm{v} / \mathrm{v}$ for digestion (amounts of skin were between 0.5 and $0.8 \mathrm{~g}$ ). They were agitated for $20 \mathrm{~h}$ at $100^{\circ} \mathrm{C}$ (after $2 \mathrm{~h}$ they were added, drop by drop, of $5 \mathrm{~mL}$ of $\mathrm{H}_{2} \mathrm{O}_{2}$ ) until the remaining solutions were of $2 \mathrm{~mL}$. The solutions were diluted with $25 \mathrm{~mL}$ of milliQ water for the analysis with ICP-MS.

\section{Analytical measurements}

The receptor fluid measurements were performed by Inductively Coupled Plasma-Mass Spectrometry (ICP-MS). An Agilent 7500ce (2005) instrument equipped with a collision cell was used for analysis. Calibration curves were obtained from four different standards at $1,5,10,50 \mu \mathrm{g}$ $\mathrm{L}^{-1}$. The limit of detection (LOD) for gold was $0.01 \mu \mathrm{g} \mathrm{L}^{-1}$ and the limit of quatification (LOQ) was $0.03 \mu \mathrm{g} \mathrm{L}^{-1}$. The correlation coefficient (r) of the standard curve was 0.9985 . The $\mathrm{CV}$ for the analysis of gold was always less than $3 \%$. 


\section{Data analysis}

Gold concentration data $\left(\mu \mathrm{g} \mathrm{cm}^{-3}\right)$ in the receptor solution (GRS) were converted to the total amount that penetrated $\left(\mu \mathrm{g} \mathrm{cm}^{-2}\right)$, considering the cell volume, the cell surface and the correction for dilution due to sample removal $(1.5 \mathrm{~mL})$ and than plotted against time. The slope of this plot gives the flux through skin $\left(\mathrm{ng} \mathrm{cm} \mathrm{cm}^{-2} \mathrm{~h}^{-1}\right)$ and the intercept of the curve with the $\mathrm{X}$-axis gives the lag time (h).

Data analysis was performed using the statistical software SPSS for Windows (version 15.0). All data were reported as mean \pm standard deviation (SD).

The difference among independent data was assessed by means of the Mann-Whitney and Kruskal Wallis tests. A $p$ value of $<0.05$ was considered as the limit of statistical significance.

\section{Skin fixation protocol for TEM analysis}

After removal some skin samples were cut into smaller sections and fixed for $3 \mathrm{~h}$ in a solution of $3 \%$ glutaraldheyde (Serva, Heildemberg, Germany) in $0.1 \mathrm{M}$ cacodylate buffer ( $\mathrm{pH} 7.3$ ). The fixed sections were washed twice (10 min each) with $0.1 \mathrm{M}$ cacodylate buffer and than post fixed with $1 \%$ osmium tetroxide for $1 \mathrm{~h}$ at $4^{\circ} \mathrm{C}$. Post-fixed samples were dehydrated with an ascending ethanol series ending to $100 \%$ ethanol and then embedded in Down epoxy resin (DER332; Unione Chimica Europea, Milan, Italy) and DER732 (Serva). The last resin embedding was made under vacuum. Semi-fine and ultra thin sec- tions were prepared with an ultra microtome Leica Ultracut UCT (Leica Microsystem, Milan, Italy) equipped with a diamond blade Drukker $3 \mathrm{~mm}$ (Emme3, Milan, Italy). Semi-fine sections were observed with an optical microscope Leitz Dialux 20 EB (Leica Microsystems, Milan, Italy) whereas ultra thin sections were double stained with lead citrate and uranyl acetate and observed with Trans- mission Electron Microscope (EM208; Philips, Heidhoven, The Netherlands) with an high definition acquisition system SIS Morada and a digital image acquisition system iTEM (FEI Italia, Milan, Italy).

\section{Results}

The AuNPs, visualized by TEM (Figure 1), were uniform in shape and size and they were as small as $12.6 \pm 0.9 \mathrm{~nm}$ (number of measured nanoparticles: 345 ) and they showed the tendency to form aggregates. The same aggregates were present in the donor solutions at the end of the $24 \mathrm{~h}$ period. In experiments 1 and 2, when AuNPs were applied in lower amount, gold passed through both the intact and the damaged human skin with a mean amount of $60.8 \pm 25.3 \mathrm{ng} \mathrm{cm}^{-2}$ and $55.2 \pm$ $27.3 \mathrm{ng} \mathrm{cm}^{-2}$ at $24 \mathrm{~h}$, respectively (Figure 2).

In experiments 3 and 4, when AuNPs were applied in higher amount, analyses revealed a higher permeation reaching in $24 \mathrm{~h} 214.0 \pm 43.7 \mathrm{ng} \mathrm{cm}$ and $187.8 \pm 50.2 \mathrm{ng} \mathrm{cm}^{-2}$ in intact and damaged skin, respectively (Mann-Whitney test: $\mathrm{p}<0.005$ between experiments 1 and 3 and 2 and 4; Figure 2).

From experiment 3 and 4 the permeation profiles of AuNPs were obtained both for intact and damaged skin (Figure 3). Twenty-four hours gold flux permeation was $7.8 \pm 2.0 \mathrm{ng} \mathrm{cm}^{-2} \mathrm{~h}^{-1}$ and 7.1 $\pm 2.5 \mathrm{ng} \mathrm{cm}-2 \mathrm{~h}^{-1}$ in intact and damaged skin, respectively $(\mathrm{p}=0.4)$, with a lag time $<1 \mathrm{~h}$.

The gold concentration in the damaged skin (exp. 4) was significantly higher in the intact skin (exp. 3) with values of $7.86 \pm 4.00 \mu \mathrm{g} \mathrm{cm}{ }^{-2}$ and $1.82 \pm 0.69 \mu \mathrm{g} \mathrm{cm} \mathrm{cm}^{-2}$, respectively $(\mathrm{p}<$ 0.009; Figure 4a).

Figure 5 shows the gold content (means \pm standard deviation) into strip numbers ranging from $0.40 \pm 0.05 \mu \mathrm{g} \mathrm{cm}^{-2}$ in the superficial strip (1st) to $0.17 \pm 0.01 \mu \mathrm{g} \mathrm{cm}^{-2}$ into the deepest strip (6th) $(\mathrm{p}<0.025)$.

The gold content in the intact skin samples (exp. 3) decreased from the epidermis, $1.74 \pm 0.68 \mu \mathrm{g}$ $\mathrm{cm}^{-2}$, to the dermis, $0.05 \pm 0.02 \mu \mathrm{g} \mathrm{cm}$ ( $1<0.005$, Figure $\left.4 \mathrm{~b}\right)$. The measurement of gold in 
the stratum corneum, epidermis and dermis of the intact skin revealed a decrease in gold content from the external to the internal site $(\mathrm{p}<0.025)$. Finally, TEM investigation revealed the presence of AuNPs into stratum corneum, epidermis and dermis (Figure 6).

\section{Discussion and conclusion}

The present study investigated the skin absorption of AuNPs using full thickness human skin (epidermis and dermis): Experiments were conducted with both intact and damaged skin in an in vitro diffusion cell system. For the first time we have obtained results that proved a dosedependent AuNPs skin penetration with TEM images into all layers of the human skin. AuNPs skin permeation is something new and there are very few data available in literature which is often scant and contradictory (Crosera et al. 2009; Baroli 2010). Actually different types of NPs have been tested, and in particular TiO2 (NANODERM 2007; Kiss et al. 2008), silver (Larese Filon et al. 2009a; Samberg et al. 2010), iron-based NPs (Baroli et al. 2007), quantum dots and carbon-based NPs (Monteiro-Riviere and Inman 2006), reporting evidence of discrepancies in nanoparticle transcutaneous penetration.

It is known that metallic ions (e.g., nickel and cobalt) are able to diffuse through the human skin (Larese Filon et al. 2004, 2007) and that silver nanoparticles have a permeation profile higher in the damaged skin than in the intact skin (Larese Filon et al. 2009a). Skin penetration can occur through pilosebaceus pores and sweat gland pores: NPs with diameter ranging between 7-20 nm are almost exclusively detected in the hair follicle infundibulum and even deeper (Schaefer et al. 1990; Lauer et al. 1996; Toll et al. 2004; Meidan et al. 2005). Vogt et al. (2006) showed that 40-nm particles were able to penetrate the perifollicular dermis through the hair follicle. For AuNPs, permeation through rat skin and intestine was already reported by Sonavane et al. (2008b), and our study confirms this capability also in human skin.

The findings of our study suggest that human skin absorption of AuNPs could be relevant both through intact and damaged skin and there is not a statistically significant difference in the amount of gold permeated in the receiving phase of the two groups of Franz cells. Moreover, this permeation is influenced by the concentration of gold in the donor phase. In the 1st and 2nd experiments the use of $15 \mu \mathrm{g} \mathrm{cm}^{-2}$ of gold in donor phases determined a lower NPgold absorption compared to that obtained in the 3rd and 4th experiments using $45 \mu \mathrm{g} \mathrm{cm}^{-2}$ of goldNP: The higher amount of gold ( 3 times) increased the permeation of about three times. There results could be also influenced by the effect of synthetic sweat on gold NP that could have increased their aggregation (with lower penetration).

The evaluation of gold content in the skin revealed that gold concentration decreased from the superficial to the deeper skin layers and a significantly higher gold amount was found in damaged skin compared to the intact skin. Skin lesions increase only the amount of gold that remains in the skin and not the concentration in the receiving phase: this is probably due to a strong interaction between NPs and skin components (cells and extracellular matrix) that brake the NPs migration; the presence of abrasions put in direct contact NPs and skin components increasing their interaction and so the quantity of gold that remain in the skin. Another reason could be that AuNP cannot release ions in physiological conditions and this aspect can change the permeation properties in intact and damaged skin in respect to other metals such as silver, nickel or cobalt (Larese Filon et al 2009a, $2009 \mathrm{~b}$ ) in which ions release influence skin permeation.

TEM images permitted us to see clearly the presence of AuNPs in all the skin layers. Sample preparation for TEM analysis is quite long and complicated, and it can results in the generation of artifacts. The special attention posed in skin sample preparation, the great number of NPs found in all the skin layers, and the comparison of size and shape of NPs inside the skin with the initial colloid solution, have allowed us to confirm, at least qualitatively, the skin penetration of AuNPs. The chemical analysis performed using ICP-MS demonstrated the presence of gold in different skin layers. 
From a toxicological point of view, our findings are relevant because they demonstrate that AuNPs can permeate the human skin in a dose-dependent way reaching the derma where these nanoparticles can be available for systemic diffusion. It has been already demonstrated that NPs administered in the dermis migrated to regional lymph nodes, potentially via skin macrophages and Langerhans cells, raising potential concern for immunomodulation (Kim et al. 2004). At the same time, the ability of AuNPs to easily permeate the skin could be taken into account for important perspectives in biomedical application and this type of NPs might be a carrier for transdermal delivery.

There are some limitations to this study that deserve attention. A limitation of our in vitro experiments is that the stratum corneum was exposed for $24 \mathrm{~h}$. Excessive hydration is known to increase penetration of many compounds. Nevertheless, people have often mechanically damaged skin such as cuts and abrasions, which would make penetration sub-stantially higher. Another limitation is that the experiments were carried out with Franz cells in which skin was static: Human skin flexion has been suggested to lead to the increased translocation of small particles into the membrane (Tinkle et al. 2003; Rouse et al. 2007) and for this reason, in this case, the in vitro results can underestimate the real situation. A third limitation is that the skin samples in this type of tests is dead tissue, and thus there is a lack regarding the possible active processes that involve living cells; on the other hand, a number of studies confirmed the usefulness of the in vitro experiments in the evaluation and prediction of percutaneous penetration (EDETOX 2000)

In conclusion, this experimental study showed that AuNPs can permeate the skin in greater amount than other NPs, such us silver nanoparticles (Larese Filon et al. 2009a), in an in vitro diffusion system. Moreover, the AuNPs cannot release Au ions in physiological condition, this penetration happens only for NPs. This is the most important result compared to that obtained using silver (Larese Filon et al. 2009) or other metal NPs that can be absorbed through the skin easily because the high surface can increase ionization. 


\section{References}

1. Balasubramanian SK, Jittiwat J, Manikandan J, Ong CN, Yu L-E, Ong WY. 2010. Biodistribution of gold nanoparticles and gene expression changes in the liver and spleen after intravenous administration in rats. Biomaterials 31:2034-2042.

2. Baroli B. 2010. Penetration of nanoparticles and nanomaterials in the skin: Fiction or reality? J Pharm Sci 99:21-50.

3. Baroli B, Ennas MG, Loffredo F, Isola M, Pinna R, Lopez-Quintela MA. 2007. Penetration of metallic nano- particles in human full-thickness skin. J Investig Dermatol 127:1701-712.

4. Bhattacharya R, Mukherjee P. 2008. Biological properties of "naked" metal nanoparticles. Adv Drug Deliv Rev 60:1289-1306.

5. Bronaugh R, Stewart R. 1985. Methods for in vitro percutaneous absorption studies. V: Permeation through damaged skin. J Pharm Sci 15:1062-1066.

6. Chen PC, Mwakwari SC, Oyelere AK. 2008. Gold nanoparticles: From nanomedicine to nanosensing. Nanotechnol Sci Applic 1:45-66.

7. Cho W-S, Cho M, Jeong J, Choi M, Cho H-Y, Han BS, Kim SH, Kim HO, Lim YT, Chung $\mathrm{BH}$, Jeong J. 2009. Acute toxicity and pharmacokinetics of $13 \mathrm{~nm}$-sized PEG-coated gold nanoparti- cles. Toxicol Appl Pharmacol 236:16-24.

8. Crosera M, Bovenzi M, Maina G, Adami G, Zanette C, Florio C, Larese Filon F. 2009. Nanoparticle dermal absorption and toxicity: A review of the literature. Int Arch Occup Environ Health 82:1043-1055.

9. Davies DJ, Ward RJ, Heylings JR. 2004. Multi-species assessment of electrical resistence as a skin integrity marker for in vivo percutaneous absorption studies. Toxicol in Vitro 18: $351-358$.

10. EDETOX 2000. Evaluations and Predictions of Dermal Absorp- tion of Toxic Chemicals, EU Framework V: Quality of Life, Environment and Health Key Action Funding Project Number: QLKA-2000-00196.

11. El-Sayed IH, Huang X, El-Sayed MA. 2006. Selective laser photo- thermal therapy of epithelial carcinoma using anti-EGFR anti- body conjugated gold nanoparticles. Cancer Lett 239:129-135.

12. Fasano W, Manning L, Green J. 2009. Rapid assessment of rat and human epidermal membrane for in vitro dermal regulatory testing: correlation of electrical resistance with tritiated water permeablity. Toxicology 255:33-37.

13. Franz TJ. 1975. On the relevance of in vitro data. J Invest Dermatol 93:633-640.

14. Ghosh P, Han G, De M, Kim CK, Rotello VM. 2008. Gold nanoparticles in delivery applications. Adv Drug Deliv Rev 17:1307-1315.

15. Gobin AM, O'Neal DP, Watkins DM, Halas NJ, Drezek RA, West JL. 2005. Near infrared laser-tissue welding using nano- shells as an exogenous absorber. Laser Surg Med $37: 123-129$.

16. Grabar CK, Griffith FR, Hommer MB, Natam MJ. 1995. Prepa- ration and characterization of $\mathrm{Au}$ colloid monolayers. Anal Chem 67:735-743.

17. Gupta AK, Gupta M. 2005. Synthesis and surface engineering of iron oxide nanoparticles for biomedical applications. Biomater- ials 26:3995-4021.

18. Hostynek JJ, Dreher F, Nakada T, Schwindt D, Anigbogu A, Maibach HI. 2001. Human stratum corneum adsorption of nickel salts. Acta Derm Venereol 81(suppl. 212):11-18.

19. Kamat PV. 2002. Photophysical, photochemical and photocatalytic aspects of metal nanoparticles. J Phys Chem B 106:7729-7744.

20. Kim S, Lim YT, Soltesz EG, De Grand AM, Lee J, Nakayama A, Parker JA, Mihaljevic T, Laurence RG, Dor DM, Cohn LH, Bawendi MG, Frangioni JV. 2004 Near-infrared fluorescent type II quantum dots for sentinel lymph node mapping. Nat Biotechnol 22:93-97. 
21. Kiss B, Biró T, Czifra G, Tóth BI, Kertész Zs, Szikszai Z, Kiss AZ, Juhász I, Zouboulis CC, Hunyadi J. 2008. Investigation of micronizided titanium dioxide penetration in human skin xeno- grafts and its effect on cellular functions of human skin-derived cells. Experiment Dermatol 17:659-667.

22. Larese Filon F, Maina G, Adami G, Venier M, Coceani N, Bussani R, Massiccio M, Barbieri P, Spinelli P. 2004. In vitro percutaneous absorption of cobalt. Int Arch Environ Health 77:85-89.

23. Larese Filon F, Adami G, Venier M, Maina G, Renzi N. 2007. In vitro percutaneous absorption of metal compounds. Toxicol Lett 170:49-56.

24. Larese Filon F, D’Agostin F, Crosera M, Adami G, Renzi N, Bovenzi M, Maina G. 2009a. Human skin penetration of silver nanoparticles through intact and damaged skin. Toxicology 255:33-37.

25. Larese Filon F, D’Agostin F, Crosera M, Adami G, Bovenzi M, Maina G. 2009b. In vitro absorption of metal powders through intact and damaged human skin. Toxicol in vitro 23:574-579.

26. Lauer AC, Ramachandran C, Lieb LM, Niemiec S, Weiner ND. 1996. Targeted delivery to the pilosebaceous unit via liposomes. Adv Drug Deliv Rev 18:311-324.

27. Lewinski N, Colvin V, Drezek R. 2008. Cytotoxicity of nanopar- ticles. Small 4:26-49.

28. Meidan VM, Bonner MC, Michniak BB. 2005. Transfollicular drug delivary - is it a reality? Int J Pharm 306:1-14.

29. Mirkin CA, Letsinger RL, Mucic RC, Storhoff JJ. 1996. A DNA-based method for rationally assembling nanoparticles into macroscopic materials. Nature 382:607-609.

30. Mironava T, Hadjiargyrou M, Simon M, Jurukovski V, Rafailovich MH. 2010. Gold nanoparticles cellular toxicity and recovery: Effect of size, concentration and exposure time. Nanotoxicology 4:120-137.

31. Monteiro-Riviere NA, Inman AO. 2006. Challenges for assessing carbon nanomaterial toxicity to the skin. Carbon 44:1070-1078.

32. NANODERM. 2007. Quality of skin as a barrier to ultra-fine particles. Final Report. Project Number: QLK4-CT-2002-02678 www.uni-leipzig.de/ nanoderm/.

33. Neuberger T, Schopf B, Hofmann H, Hofmann M, von Rechenberg B. 2005. Superparamagnetic nanoparticles for biomedical applications: possibilities and limitations of a new drug delivery system. J Magn Magn Mat 293:483-496.

34. Niidome T, Yamagata M, Okamoto Y, Akiyama Y, Takahashi H, Kawano T, Katayama Y, Niidome Y. 2006. PEG-modified gold nanorods with a stealth character for in vivo applications. J Control Release 114:343-347.

35. Penn SG, He L, Natan MJ. 2003. Nanoparticles for bioanalysis. Curr Opin Chem Biol 7:609-615.

36. Pernodet N, Fang X, Sun Y, Bakhtina A, Ramakrishnan, Sokolov J, Ulman A, Rafailovich M. 2006. Adverse effects of citrate/Gold nanoparticles on human dermal fibroblasts. Small 6:766-773.

37. Ratto F, Matteini P, Rossi F, Menabuoni L, Tiwari N, Kulkarni SK, Pini R. 2009. Photothermal effects in connective tissues mediated by laser-activated gold nanorods. Nanomed- Nanotechnol 5:143-151.

38. Rosi NL, Giljohann DA, Shad Thaxton C, Lytton-Jean AKR, Han MS, Mirkin CA. 2006. Oligonucleotide-modified gold nanoparticles for intracellular gene regulation. Science 312:1027-1030.

39. Rouse JG, Yang J, Ryman-Rasmussen JP, Barron AR, Monteiro-Riviere NA. 2007. Effects of mechanical flexion on the penetration of fullerene amino acid-derivatized peptide nanoparticles through skin. Nano Lett 7:155-160.

40. Samberg ME, Oldenburg SJ, Monteiro-Riviere NA. 2010. Evalu- ation of silver nanoparticle toxicity in skin in vivo and keratino- cytes in vitro. Environ Health Perspect 118:407-413. 
41. Schaefer H, Watts F, Brod J, Illel B. 1990. Follicular penetration. In: Scott RC, Guy RH, Hadgraft $\mathrm{J}$, editors. Prediction of percutaneous penetration. Methods, measurements, modeling. London: IBC Technical Services. pp 163-173.

42. Semmler-Behnke M, Kreyling WG, Lipka J, Fertsch S, Wenk A, Takenaka S, Schmid G, Brandau W. 2008. Biodistribution of 1.4- and 18-nm gold particles in rats. Small 4:21082111.

43. Sonavane G, Tomoda K, Makino K. 2008a. Biodistribution of colloid gold nanoparticles after intravenous administration: Effect of particle size. Colloids Surf B Biointerfaces 66:274-280.

44. Sonavane G, Tomoda K, Sano A, Ohshima H, Terada H, Makino K. 2008b. In vitro permeation of gold nanoparticles through rat skin and rat intestine: Effect of particle size. Colloids Surf B Biointerfaces 65:1-10.

45. Takahashi H, Niidome Y, Niidome T, Kaneko K, Kawasaki H, Yamada S. 2006. Modification of gold nanorods using phos- phatidylcholine to reduce cytotoxicity. Langmuir $22: 2-5$.

46. Tian ZQ, Ren B, Wu DY. 2002. Surface-enhanced Raman scat- tering: From noble to transition metals and from rough surfaces to ordered nanostructures. J Phys Chem B 106:9463-9483.

47. Tinkle SS, Antonini JM, Rich BA, Roberts JR, Salmen R, De Pree K. 2003. Skin as a route of exposure and sensitization in chronic beryllium disease. Environ Health Perspect 111:1202-1208.

48. Toll R, Jacobi U, Richter H, Laedmann J, Shaefer H, Blume-Peytavi U. 2004. Penetration profile of microspheres in follicular targeting of terminal hair follicles. J Invest Dermatol 123:168-176.

49. Vogt A, Combadiere B, Hadam S, Stieler KM, Lademann J, Schaefer H. 2006. 40 nm, but not 750 or $1500 \mathrm{~nm}$, nanoparticles enter epidermal CD1a + cells after transcutaneous application on human skin. J Invest Dermatol 126:1316-1322.

50. Wang S, Lu W, Tovmachenko O, Rai US, Yu H, Ray PC. 2008. Challenge in understanding size and shape dependent toxicity of gold nanomaterials in human skin keratinocytes. Chem Phys Lett 463:145-149. 
Figure 1. AuNPs visualized by TEM

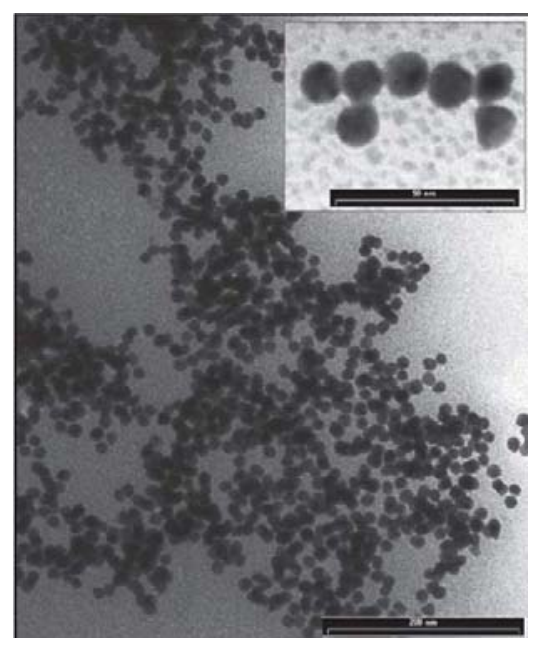

Figure 2. AuNPs permeation at 24 hours in intact and damaged skin (exp. 1-2 and exp. 34)

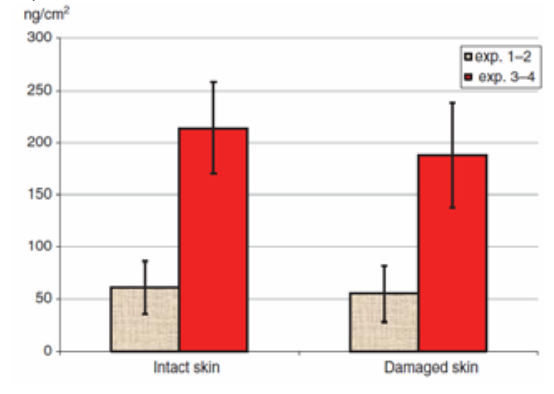

Figure 3. AuNPs permeation profiles in intact and damaged skin (exp. 3-4)

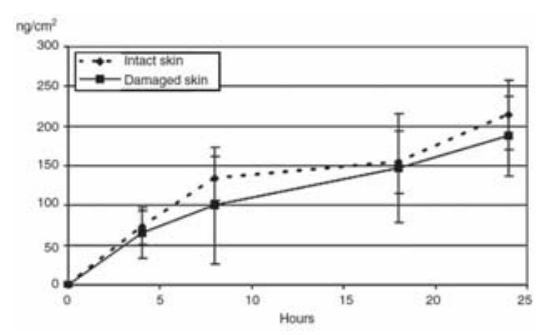

Figure 4. (a) Gold content (exp. 3-4) into damaged and intact skin (means and standard deviation; *p < 0.009); (b) Gold content (exp. 3) into epidermis and dermis of intact skin samples (means and standard deviation; *p < 0.005)

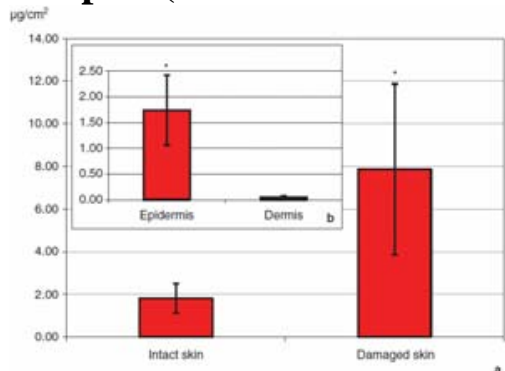


Figure 5. Gold content (exp. 3) into stratum corneum tape stripping (means and standard deviation; $\left.{ }^{*} \mathbf{p}<0.025\right)$. From 1 st more superficial to 6 th more deep

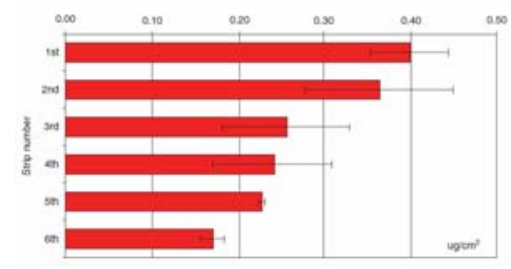

Figure 6. (a) TEM micrograph of AuNPs-treated skin sample (Barr $=10 \mathrm{~mm})$. (b, c, d) Some details of the stratum corneum (b, c.), and of the dermis (d) Black arrows show gold nanoparticles in the tissue. $($ Barr $=200 \mathrm{~nm})$

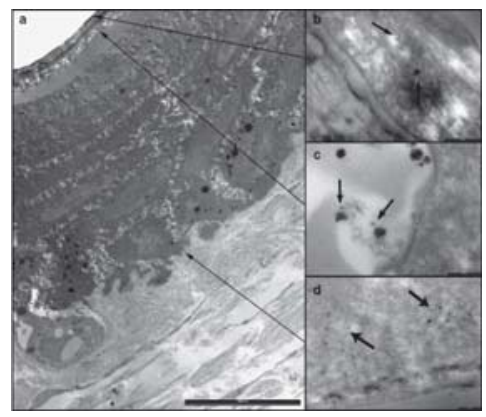

